\title{
Domates Ekstraktının Saccharomyces cerevisiae'de Oluşturulan Krom Hasarına Karşı Koruyucu Etkisi
}

\author{
Abdullah ASLAN ${ }^{*}$ ID, Seda BEYAZ ${ }^{2}$, Özlem GÖK ${ }^{2}$ \\ 1*: Frrat Üniversitesi Fen Fakültesi Biyoloji Bölümü Moleküler Biyoloji ve Genetik Programı \\ 2: Frrat Üniversitesi Fen Fakültesi Biyoloji Bölümü
}

Geliş / Received: 08/04/2019, Kabul / Accepted: 11/07/2019

\section{$\ddot{O} z$}

Bu çalışmada 4 grup oluşturulmuştur. Gruplar: (i) Kontrol grubu; (ii) Domates ekstraktı grubu (DE); (iii) Krom grubu; (iv) DE + Krom grubu. S. cerevisiae kültürleri 1 saat, 3 saat, 5 saat ve 24 saat boyunca $30{ }^{\circ} C^{\prime}$ de geliştirildi. Hücre gelişimi ve lipit peroksidasyonu MDA (malondialdehit) analizleri spektrofotometre ile belirlendi. Total protein değişiklikleri SDS-PAGE elektroforezi ile tespit edildi ve Bradford metodu ile hesaplandı. Elde edilen sonuçlara göre; krom grubu ile kıyaslandığında hücre gelişimi ve total protein sentezi, DE' de (1, 3, 5 ve 24 saat) artarken, MDA seviyesinde azalış göstermiştir. Sonuç olarak DE'nin S. cerevisiae kültüründe oksidatif hasarı azaltmasının yanı sıra, hücre büyümesini ve total protein sentezini teşvik edici bir role sahip olduğunu söyleyebiliriz.

Anahtar Kelimeler: Saccharomyces cerevisiae, SDS-PAGE, Domates ekstrakt1, Krom, protein, oksidatif hasar

\section{The Protective Effect of Tomato Extract Against to Chromium-Induced Damage in Saccharomyces cerevisiae}

\begin{abstract}
In this study 4 groups were formed. Groups: (i) Control group; (ii) Tomato extract Group (DE); (iii) Chromium group; (iv) Tomato extract + Chromium group. S. cerevisiae cultures were developed at $30^{\circ} \mathrm{C}$ for 1 hour, 3 hours, 5 hours and 24 hours. Cell development and lipid peroxidation MDA (malondialdehyde) analyzes were determined by spectrophotometer. Total protein changes were determined by SDS-PAGE electrophoresis and calculated by the Bradford method. According to the results, cell development and total protein synthesis increased in the Tomato extract + Chromium group (1, 3, 5 and 24 hours) and MDA level decreased compared to the chromium group. As a result, tomato extract has a role in promoting cell growth and total protein synthesis as well as reducing oxidative damage in S. cerevisiae culture.
\end{abstract}

Key words: Saccharomyces cerevisiae, SDS-PAGE, Tomato extract, Chromium, Protein, Oxidative damage

\section{Giriş}

Son yıllarda yapılan çalışmalarda değişik meyve ekstraktlarının farklı hastalıkların önlenmesi ve tedavisine katkı sağladığ1 belirtilmiştir (Park vd., 2014). Fenolik bileşikler, domates ve domates ürünlerinde çok fazla bulunmakla birlikte çeşitli hastalıklara karşı korunma sağlamaktadır. Domates besin bileşimi bakımından karbohidrat (\% 3), protein (\% 12), lipit (\% 1), mineraller (kalsiyum, magnezyum, fosfor, potasyum, sodyum, çinko) ve vitamin (A ve $\mathrm{C}$ vitaminleri) içermektedir. Domates ve domates türevli ürünlerin antioksidan, antienflamatuar ve antikanser özelliklere sahip olduğu belirlenmiş̧tir. Ayrıca hücreler arası iletişim, metabolik ve immün sistemin düzenlenmesinde önemli 
bir role sahiptir. Buna ilave olarak domatesin lipit peroksitlerin serum seviyeleri ve düşük yoğunluklu lipoprotein (LDL) oksidasyonu üzerindeki olumlu etkiye sahip olduğu çeşitli çalışmalarla belirlenmiştir (Salehi vd., 2019). Reaktif oksijen türleri (ROS); nükleik asit, protein, yağ ve karbonhidratları etkileyebilmektedir. Oksidatif hasar antioksidan savunma ile önlenmektedir. Ancak antioksidan savunma sistemi yetersiz kaldığında, hücrede oksidatif hasar olmaktadır (Aslan vd., 2017). Hücresel antioksidan savunma mekanizmaları ROS'u etkili bir şekilde ortadan kaldıramadığında oksidatif strese yol açmaktadır. Hidrojen peroksit, lipidlerin, proteinlerin ve DNA'nın geri dönüşümsüz hasarına yol açarak hücre organellerinin işlevsizliğine neden olmaktadır. Kanser, arteriyoskleroz, diyabet ve nörodejeneratif hastalıklar gibi birçok hastalığın gelişmesine neden olduğu bilinmektedir (Jacewicz vd., 2017). S. cerevisiae'nin genetik yapısı bilindiğinden dolayı bilimsel çalışmalarda model olarak kullanılmaktadır (Aslan vd., 2017).

$\mathrm{Bu}$ çalışmada $\mathrm{S}$. cerevisiae kültürüne hidrojen peroksit uygulanarak hasar oluşturulmuş ve bu canlıdaki domatesin hücre büyümesine karşı etkileri incelenmiştir.

\section{Materyal ve Metot}

\subsection{Araştırma Grupları}

$\mathrm{Bu}$ çalışmada 4 grup oluşturulmuştur. Gruplar: (i) Kontrol Grubu; (ii) Domates ekstraktı Grubu (DE): Domates (\% 10) verilen grup; (iii) Krom Grubu: Krom (10 milimolar) verilen grup; (iv) $\mathrm{DE}+$ Krom Grubu: DE (\% 10) + Krom(10 milimolar) verilen grup. Sterilizasyondan hemen sonra, DE (\% 10) ve Krom (10 milimolar),
Saccharomyces cerevisiae (S. cerevisiae) kültürlerine eklenmiş ve kültürler, 1 saat, 3 saat, 5 saat ve 24 saat boyunca (gece boyunca) $30^{\circ} \quad C^{\prime} d e$ geliştirildi. $S$. cerevisiae'nin gelişim ortamı: Mayaların geliştirilmesi ve çoğaltılması için, YEPD (50 mL için; $1.5 \mathrm{~g}$ maya özütü, $1.5 \mathrm{~g}$ tripton, $1.5 \mathrm{~g}$ glukoz) ilave olarak $S$. cerevisiae'nin büyümesi ve çoğaltılması için DE eklendi ve geliştirildi. Sterilizasyondan sonra numune örnekleri 1 saat, 3 saat, 5 saat ve 24 saat boyunca (gece boyunca) $30^{\circ} \mathrm{C}^{\prime} \mathrm{de}$ geliştirildi (Aslan vd., 2017).

\subsection{Kültüre domates ekstraktı ve krom kimyasalı uygulanması}

Domates (\% 10) ve Krom (10 milimolar) $S$. cerevisiae ortamina eklendi ve $30^{\circ} \mathrm{C}^{\prime} \mathrm{de}$ geliştirildi. Krom; Krom grubu (10 milimolar) ve domates $(\% 10)+$ Krom $(10$ milimolar) grubuna eklendi.

\subsection{Hücre Gelişimi Ölçümleri}

Kültür örnekleri 1 saat, 3 saat, 5 saat ve 24 saat boyunca (gece boyunca) $30^{\circ} \mathrm{C}^{\prime} \mathrm{de}$ geliştirildi ve $600 \mathrm{~nm}$ dalga boyunda spektrofotometre kullanılarak ölçümleri yapild1.

\subsection{SDS- PAGE (Sodyum Dodesil Sülfat-Poliakrilamid Jel Elektroforez) Analizi}

S. cerevisiae kültürlerinin örnekleri, SDSPAGE için hazırland. Sonra protein örnekleri SDS PAGE ile analiz edildi. Jel görüntüleri alınarak gruplar arasındaki protein bantları incelendi (Laemmli, 1970).

\subsection{MDA (Malondialdehit) Analizi}

MDA tayininde, gruplardan $200 \mu$ örnek alınarak \% 8,1 SDS'ten $200 \mu$ l ilave edilmiştir. \% 20'lik asetik asit'ten (pH: 3,5) 
1,5 ml ve \% 0,8'lik (pH: 3,5) TBA'dan 1,5 $\mathrm{ml}$ eklenerek son hacim $4 \mathrm{ml}$ olacak şekilde distile su eklenmiştir. Daha sonra $95^{\circ} \mathrm{C}$ sicakl1kta kaynar su banyosunda 1 saat beklenecek ve ardından soğutularak $1 \mathrm{ml}$ distile su 15:1 (v/v) oranında $5 \mathrm{ml} \mathrm{n}$ butanol-piridin karışımından eklenip vortekslenmiştir. 4000 rpm'de 15 dakika santrifüj edildikten sonra üstteki organik tabaka alınıp $532 \mathrm{~nm}$ dalga boyunda spektrofotometrik olarak ölçülmüştür. Sonuçlar nmol/ml olarak kaydedilmiştir (Ohkawa vd., 1979; Aslan vd., 2018).

\section{6. İstatistiksel Analizler}

Bütün veriler SPSS 22 paket programında varyans analizi ile değerlendirilmiştir. Gruplar içi farklılıkları belirlemek için One Way Anova Post Hoc Tukey ve LSD testleri uygulanmıştır. Yapılan istatistiklerin güvenirliliği açısından ölçümler en az 3 tekrar olacak şekilde yapılmıştır.

\section{Tartışma ve Sonuç}

$\mathrm{Bu}$ çalışmadan elde edilen sonuçların mevcut literatüre önemli katkılar sunacağını düşünüyoruz. Şekil 1'e göre farklı gelişim zamanları olan gruplar arasinda anlamlı bir fark olduğu gözlenmektedir $(\mathrm{p}<0,05)$. Kültür ortamına aktarılan domates ekstraktının (DE), kromun olumsuz etkisine karşı hücre gelişimini arttırdı̆̆ görülmüştür.

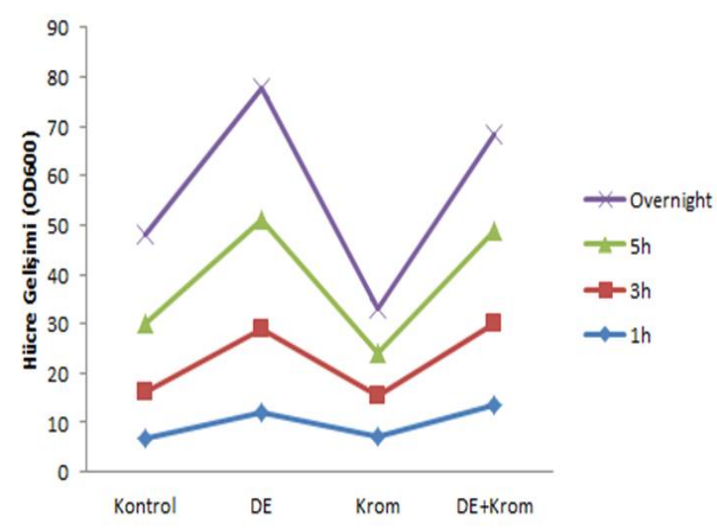

Şekil 1. S. cerevisiae' nin domateste farklı saatlerdeki hücre gelişimi

Tablo 1, Tablo 2, Şekil 2, Şekil 3 ve 4'de verilen total protein sonuçları incelendiğinde, DE'nin, S. cerevisiae'de protein sentezini teşvik ettiğini söyleyebiliriz. Özellikle krom grubu ile kıyaslandığında DE (\% 10) + Krom (10 milimolar) grubunda yüksek oranda arttı̆̆ görülmektedir.

Tablo 1. Bradford Pelet Total Protein Yoğunlukları

\section{GRUPLAR (Pelet) Total Protein Yoğunluğu $(\mu \mathrm{g} / \mathrm{ml})$}

\begin{tabular}{ll}
\hline Kontrol & $120,33 \pm 4,04^{\mathrm{a}}$ \\
DE & $113,37 \pm 2,07^{\mathrm{a}}$ \\
Krom & $37,19 \pm 3,06^{\mathrm{c}}$ \\
DE + Krom & $87,26 \pm 3,01^{\mathrm{b}}$ \\
\hline
\end{tabular}


Tablo 2. Bradford Süpernatant Total Protein Yoğunlukları

\begin{tabular}{ll}
\hline GRUPLAR (Süpernatant) & Total Protein Yoğunluğu $(\boldsymbol{\mu g} / \mathbf{m l})$ \\
\hline Kontrol & $29,02 \pm 2,00^{\mathrm{a}}$ \\
DE & $29,03 \pm 2,01^{\mathrm{a}}$ \\
Krom & $22,02 \pm 2,00^{\mathrm{c}}$ \\
DE + Krom & $26,35 \pm 2,08^{\mathrm{b}}$ \\
\hline
\end{tabular}

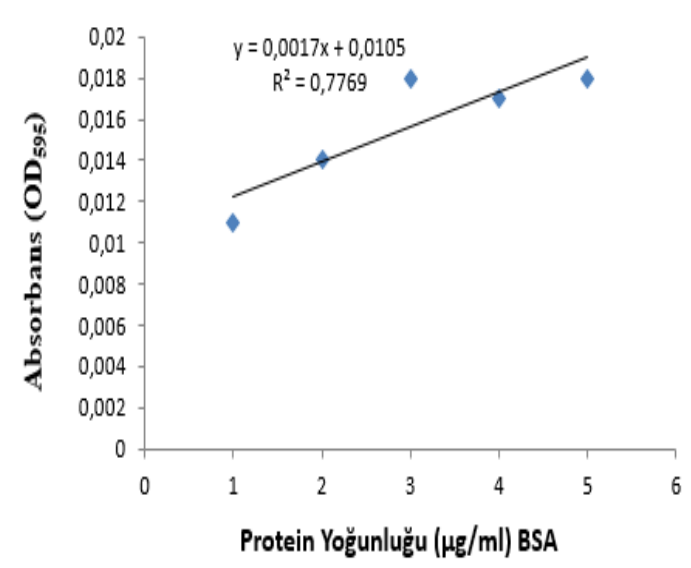

Şekil 2. Bradford BSA (bovine serum albumin) Standart Grafiği

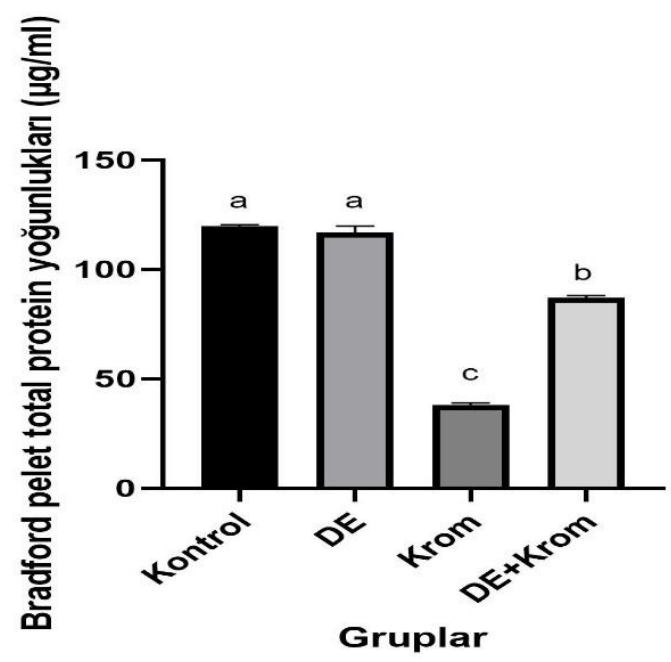

Şekil 3. Gruplar arası pelet total protein yoğunlukları

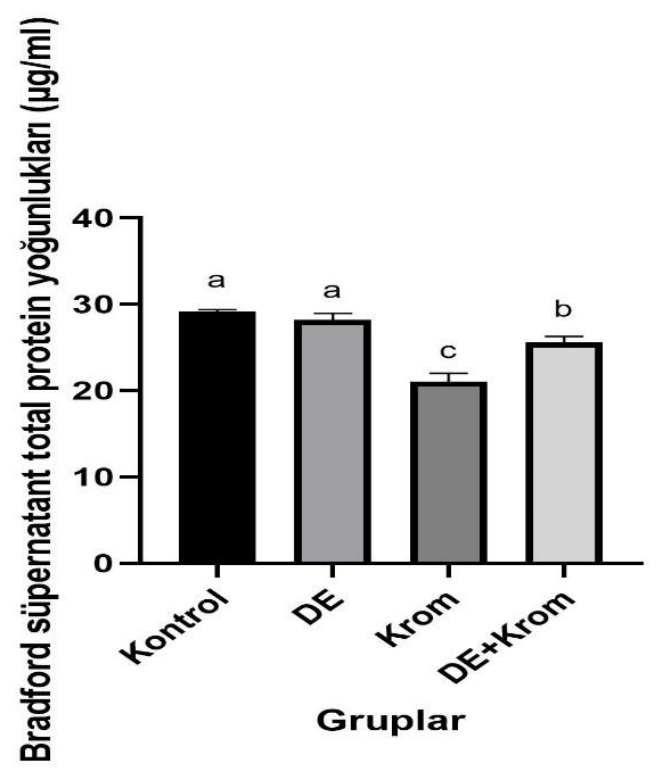

Şekil 4. Gruplar arası süpernatant total protein yoğunlukları

Tablo 3, Şekil 5 ve Şekil 6'da verilen MDA seviyelerini incelediğimizde; krom grubunda MDA seviyesinin en yüksek olduğu, DE (\% 10) + Krom (10 milimolar) grubunda ise anlamlı bir şekilde azaldığı gözlemlenmiştir.

Tablo 3. MDA düzeyleri

\begin{tabular}{ll}
\hline GRUPLAR & $\begin{array}{l}\text { MDA düzeyleri } \\
(\mathbf{n m o l} / \mathbf{m l})\end{array}$ \\
\hline Kontrol & $1,11 \pm 0,02^{\mathrm{c}}$ \\
DE & $0,09 \pm 0,05^{\mathrm{c}}$
\end{tabular}




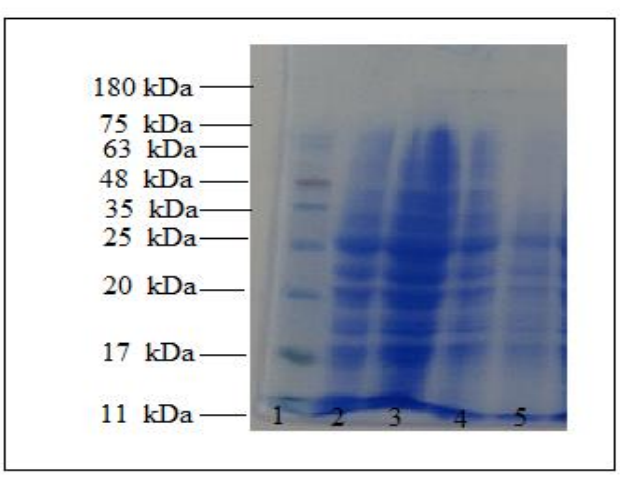

$$
\begin{array}{ll}
\text { Krom } & 2,89 \pm 0,03^{\mathrm{a}} \\
\mathbf{D E}+\text { Krom } & 2,25 \pm 0,01^{\mathrm{b}}
\end{array}
$$

a-c: Sütunlarda farklı harfi taşıyan gruplar arası fark önemlidir $(\mathrm{p}<0,05)$. One- Way ANOVA Post Hoc LSD Testi

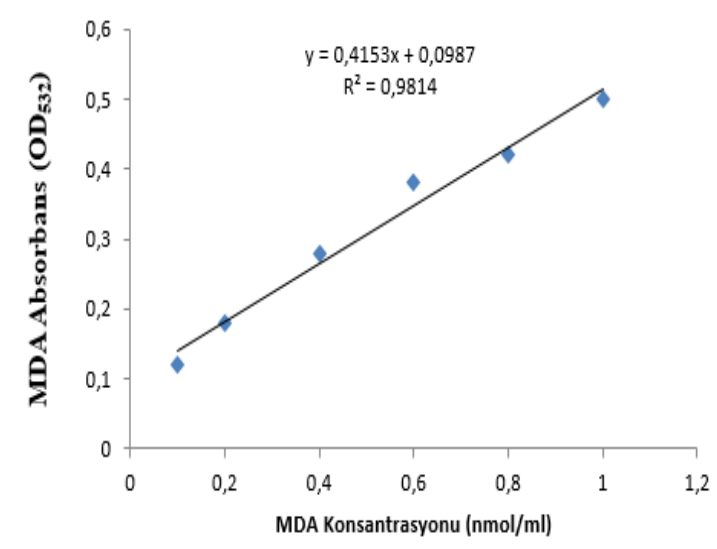

Şekil 5. MDA Standart Grafiği

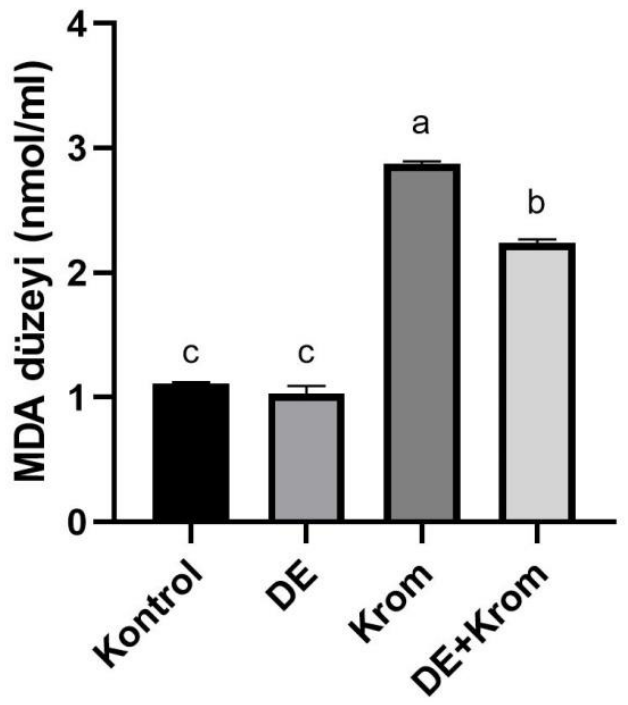

Gruplar

Şekil 6. Gruplar arası MDA düzeyleri

Şekil 7'deki SDS-PAGE jel görüntüsü incelendiğinde; protein yoğunluğunun, krom grubuna kıyasla DE $(\% 10)+$ Krom (10 milimolar) grubunda yüksek oranda arttığ1 gözlenmektedir.

\section{Şekil 7. SDS- PAGE Pelet Protein}

Bantlar1. Bantlar 1: Marker; 2: Kontrol; 3:

DE; 4: Krom; 5: DE + Krom

$\mathrm{Bu}$ çalışma sonucunda, domatesin kromun olumsuz etkilerine rağmen $S$. cerevisiae'nin gelişimini arttırdığı sonucuna varılmıştır. Aslan vd. (2014a), S. cerevisiae'de farkl1 şeker kaynaklarının bazı vitaminlerin ve yă asitlerinin sentezinde değişikliklere neden olduğunu belirtmişlerdir. Aslan ve Can (2015a), üzüm ekstraktının $S$. cerevisiae kültüründe oksidatif hasarı azaltarak hücre büyümesini $\operatorname{arttırdığ1~}$ sonucuna varmışlardır. Karatay vd. (2014a), bademin yağ asidi ve protein içeriği bakımından insan sağlığı için faydalı olduğu sonucuna varmışlardır. Aslan ve Can (2015b), portakal suyunun $S$. 
cerevisiae'de oksidatif hasarı azaltmasının yanı sıra hücre büyümesini ve protein sentezini arttırmada koruyucu bir role sahip olduğunu belirtmişlerdir. Soquetta vd. (2016), kivi meyvesinin bazı mikroorganizmaların proliferasyonu azalttığını tespit etmişlerdir. Aslan (2015), farklı meyve suları ve bunların kombinasyonlarının, S. cerevisiae'de oksidatif hasarı azaltma ve hücre büyümesini arttırmada koruyucu bir rolü olduğunu vurgulamıştır. Park vd. (2014), kivi ekstraktının farklı hastalıkların inhibisyonunda ve tedavisinde etkili olduğu sonucuna varmışlardır. Aslan vd. (2017), kivi ekstraktının antioksidan özelliği sayesinde $S$. cerevisiae'de oksidatif hasarı azaltarak, hücre büyümesini arttırdığını belirtmişlerdir. Wang, vd. (2017), kivi meyvesinin antioksidan özelliğe sahip olduğunu ve insan sağlı̆̆ açısından koruyucu olduğunu ortaya koymuşlardır. Aslan vd. (2014b), nar suyunun $S$. cerevisiae büyümesi üzerinde koruyucu bir role sahip olduğunu belirtmişlerdir. Gök (2017), $\mathrm{CCl}_{4}$ ile karaciğer hasarı oluşturulan sıçanlarda Ellagik asit'in (EA) koruyucu etkisini araştırmıştır. Karaciğer dokusunda, EA verilen gruplarda MDA seviyesinin düştüğünü ve $\mathrm{CCl}_{4}$ gruplarında $\mathrm{MDA}$ seviyesinin en yüksek düzeye ulaştığını ortaya koymuşlardır. Pan vd. (2018), endojen likopenin asetik asitin neden olduğu hücre içi ROS seviyesini azalttığı ve hücre büyümesini arttırdığını tespit etmişlerdir. Alugoju vd. (2018), quersetinin S. cerevisiae'yi apoptotik hücre ölümünden koruduğu ve hücre canlılığını arttırdığını; Vazquez vd. (2017), melatonin, $S$. cerevisiae' de hidrojen peroksitin neden olduğu oksidatif stres hasarını azalttı ğ1 belirtmişlerdir. Aslan (2018), dut ekstraktının $S$. cerevisiae' de $\mathrm{H}_{2} \mathrm{O}_{2}$ hasarına karşı önemli derecede koruma sağlayarak hücre büyümesini arttırdığını belirtmiştir.

$\mathrm{Bu}$ sonuçlar değerlendirildiğinde; domates ekstraktının $S$. cerevisiae'de kromun oluşturduğu oksidatif hasara karşı etkili olduğunu, total protein sentezini teşvik ettiği, hücre gelişimini arttırdığını, hücreyi oksidatif hasara karşı koruduğunu söyleyebiliriz. Bu bulguların, hayvanlar ve insanlar üzerinde de yapilacak olan çalışmaları destekleyeceğini ve benzer sonuçlar alınacağını umuyoruz.

\section{Kaynaklar}

Alugoju, P., Periyasamy, L. and Dyavaiah, M. (2018). Quercetin Enhances Stress Resistance in Saccharomyces cerevisiae tel1 Mutant Cells to Different Stressors. Journal of Food Science and Technology, 55 (4), 1455-1466.

Aslan, A. (2015). The Effects of Different Essential FJ and their Combination on Saccharomyces cerevisiae Cell Growth. Progress in Nutrition, 17 (1), 36-40.

Aslan, A. (2018). Cell Culture Developing and the İmaging of Total Protein Product Changing with SDS-PAGE in Saccharomyces cerevisiae. Progress Nutrition, 20 (1), 128-132.

Aslan, A. and Can, M.I. (2015a). The İnhbition of Chromium Effect in Saccharomyces cerevisiae Thrive from Grapefruit. Progress in Nutrition, 17 (4), 339-342.

Aslan, A. and Can, M.I. (2015b). The Effect of Orange Juice against to $\mathrm{H}_{2} \mathrm{O}_{2}$ Stress in Saccharomyces cerevisiae. Progress in Nutrition, 17 (3), 250-254. 
Aslan, A., Baspinar, S. and Yilmaz, O. (2014b). Is Pomegranate Juice has a Vital Role for Protective Effect on Saccharomyces cerevisiae Growth?. Progress in Nutrition, 16 (3), 212-217.

Aslan, A., Can, M.I. and Boydak, D. (2014a). Anti-Oxidant Effects of Pomegranate Juice on Saccharomyces cerevisiae Cell Growth. Afr J Tradit Complement Altern Med, 11 (4), 14-18

Aslan, A., Gök, Ö. and Erman, O. (2017). The Protective Effect of Kiwi Fruit Extract Against to Chromium Effect on Protein Expression in Saccharomyces cerevisiae. Progress in Nutrition, 19 (4), 472-476.

Aslan, A., Gök, Ö., Erman, O. and Kuloğlu, T. (2018). Ellagic Acid İmpedes Carbontetrachloride-İnduced Liver Damage in Rats Through Suppression of NF-kB, Bcl-2 and regulating Nrf-2 and caspase pathway. Biomedicine \& Pharmacotherapy, 105, 662-669.

Gök, Ö. (2017). Karbon Tetraklorür ile Karaciğer Hasarı Oluşturulmuş Sıçanlarda Ellagik Asitin Bazı Apoptotik Proteinlerin İfadesine Etkisi. Yüksek Lisans Tezi, Frrat Üniversitesi Fen Bilimleri Enstitüsü, Elazı̆.

Jacewicz, D., Siedlecka-Kroplewska, K., Drzeżdżon, J., Piotrowska, A., Wyrzykowski, D., Tesmar, A., Zamojc, K. and Chmurzyński, L. (2017). Method for Detection of Hydrogen Peroxide in HT22 Cells. Scientific Reports, 7, 45673.

Karatay, H., Sahin, A., Yilmaz, Ö. ans Aslan, A. (2014). Major Fatty Acids Composition of 32 Almond (Prunus dulcis [Mill.] DA Webb) Genotypes Distributed in East and Southeast of Anatolia. Turkish
Journal of Biochemistry/Turk Biyokimya Dergisi, 39 (3), 307-316.

Laemmli, U.K. (1970). Cleavage of Structural Proteins During the Assembly of the Head of Bacteriophage T4. Nature, 227, 680-685.

Ohkawa, H., Ohishi, N. and Yagi, K. (1979). Assay for Lipid Peroxides in Animal Tissues by Thiobarbituric Acid Reaction. Analyses of Biochemichal, 95, 351-358.

Pan, S., Jia, B., Liu, H., Wang, Z., Chai, M. Z., Ding, M. Z., Zhou, X., Li, X., Li, C., Li, B. and Yuan, Y.J. (2018). Endogenous lycopene improves ethanol production under acetic acid stress in Saccharomyces cerevisiae. Biotechnology for Biofuels, 11 (1), 107.

Park, Y.S., Namiesnik. J., Vearasilp, K., Leontowicz, H., Leontowicz, M., Barasch, D., Nemirovski, A., Trakhtenberg, S., Gorinstein, S. (2014). Bioactive Compounds and the Antioxidant Capacity in New Kiwi Fruit Cultivars. Food Chemistry, 165, 354-361.

Salehi, B., Sharifi-Rad, R., Sharopov, F., Namiesnik, J., Roointan, A., Kamle, M., Kumar, P., Martins, N. and Sharifi-Rad, J. (2019). Beneficial Effects and Potential Risks Of Tomatoes Consumption For Human Health: An Overview. Nutrition, 62, 201-208.

Soquetta, M.B., Stefanello, F.S., Mota Huerta, K., Monteiro, S.S., Rosa, C. S. and Terra, N.N. (2016). Characterization of Physiochemical and Microbiological Properties, and Bioactive Compounds, of Flour Made from the Skin and Bagasse of 
Kiwi Fruit (Actinidia deliciosa). Food chemistry, 199, 471-478.

Vázquez, J., González, B., Sempere, V., Mas, A., Torija, M. J. and Beltran, G. (2017). Melatonin Reduces Oxidative Stress Damage İnduced by Hydrogen Peroxide in Saccharomyces cerevisiae. Frontiers in Microbiology, 8, 1066.

Wang, Y., Shan, T., Yuan, Y., Zhang, Z., Guo, C. and Yue, T. (2017). Evaluation of Penicillium expansum for Growth, Patulin Accumulation, Nonvolatile Compounds and Volatile Profile in Kiwi Juices of Different Cultivars. Food Chemistry, 228, 211-218. 